\title{
THE INFLUENCE OF COMIC STRIPS MEDIA IN TEACHING WRITING SKILL TO THE TENTH GRADE STUDENTS IN CIANJUR
}

\author{
Syifa Butsainah Ulfa Suherman ${ }^{1}$, Evie Kareviati ${ }^{2}$ \\ 1,2 IKIP Siliwangi \\ ${ }^{1}$ syifabutsa@student.ikipsiliwangi.ac.id, 2 ekareviati@ gmail.com
}

\begin{abstract}
Writing is an important skill for students because it helps them in their life but sometime they have difficulties when they start to writing. Therefore, the teacher must be able to find and use the right strategies for teaching writing activity especially choosing teaching media. One of the media that can be used in teaching writing is comic strips. The objective of this research is to find out whether there is an influence of using comic strips media to improve writing skill in the tenth grade students. This research employed pre-experimental design and used test questions as the instrument. The sample was the tenth grade students in one of SMKN in Cianjur, consisting of 36 students. The research compared the mean of the pre-test and post-test to identify the influence of comic strips media in improving writing skill.
\end{abstract}

Keywords: Comic strips, Improving, Writing Skill

\section{INTRODUCTION}

Writing skill is one of the four skills in English namely speaking, listening, reading and writing that must be mastered by students in learning English. (Blanchard et al., 1998) as cited in (Hidayah et al., 2019) state that learning to write in a new language is not always easy. There are many things that students must pay attention to. According to (Apsari, 2018) there are several components in writing that have to be considered including word choice, use of appropriate grammar, syntax, mechanics, and organization of ideas into coherent and cohesive form.

Furthermore, (Scott, 1990: 69) as cited in (Yulianti et al., 2019) defines writing is an interesting activity. It is a useful, essential integral, enjoyable and gives advantages even though there are difficulties in writing. And also (Alves, 2008) as cited in (Farizi \& Fauzyah, 2019) state that writing is the way of communication between the writer and the readers. Thus, it is important for students to learn writing.

In the preliminary observation, the researcher found that the students had problem when they started to writing. They felt confused and afraid of making mistakes even though they have not tried writing yet, they did not know where to start and end it. In addition (Lestari et al., 2019) states that students have some difficulties in writing such as lack of vocabulary and low motivation to write. Beside that, there are also word choice, incorrect grammar, poor organization, unstructured content, and mechanics (punctuation, capitalization and spelling). Therefore, it is important for teacher to find and use the right strategies in teaching especially the selection of teaching media. 
Media refers to anything that carries information between a source and receiver and also considered as instructional system of teaching process. (Janah, 2016) as cited in (Herliana \& Daniawati, 2018) explains that the tools for a learning event are very effective for the achievement of learning objective and will help teacher more creativity in deliver the materials more clearly and reach the goal of learning.

Comic strips is a comic that consist of several picture panels and containing text inscribed within "balloons" inside the picture frame, that are designed to be read as a narrative sequence. Comic strips is essentially a mass media, printed in magazine, a newspaper, and a book. It is an interesting story in form of pictures and texts as the complement. It often influences the students' emotion and feeling while conceiving the story and developing their imagination because each comic strips has various stories such as tell about humor, mystery, adventure, action, love and so on. So comic strips can be used as media in teaching-learning.

(Swain, 1978) as cited in (Mahir \& Ali, 2016) argues that comics are effective to be used as teaching materials in language classes as they do not refrain students from reading other materials and also comic spark laughter or amusement that will have great influence to attract students' attention in learning activities. Through the teaching learning activities using the comic strips, students could express what they have seen, read and pour their ideas into writing.

Picture 1. Example of Comic Strips
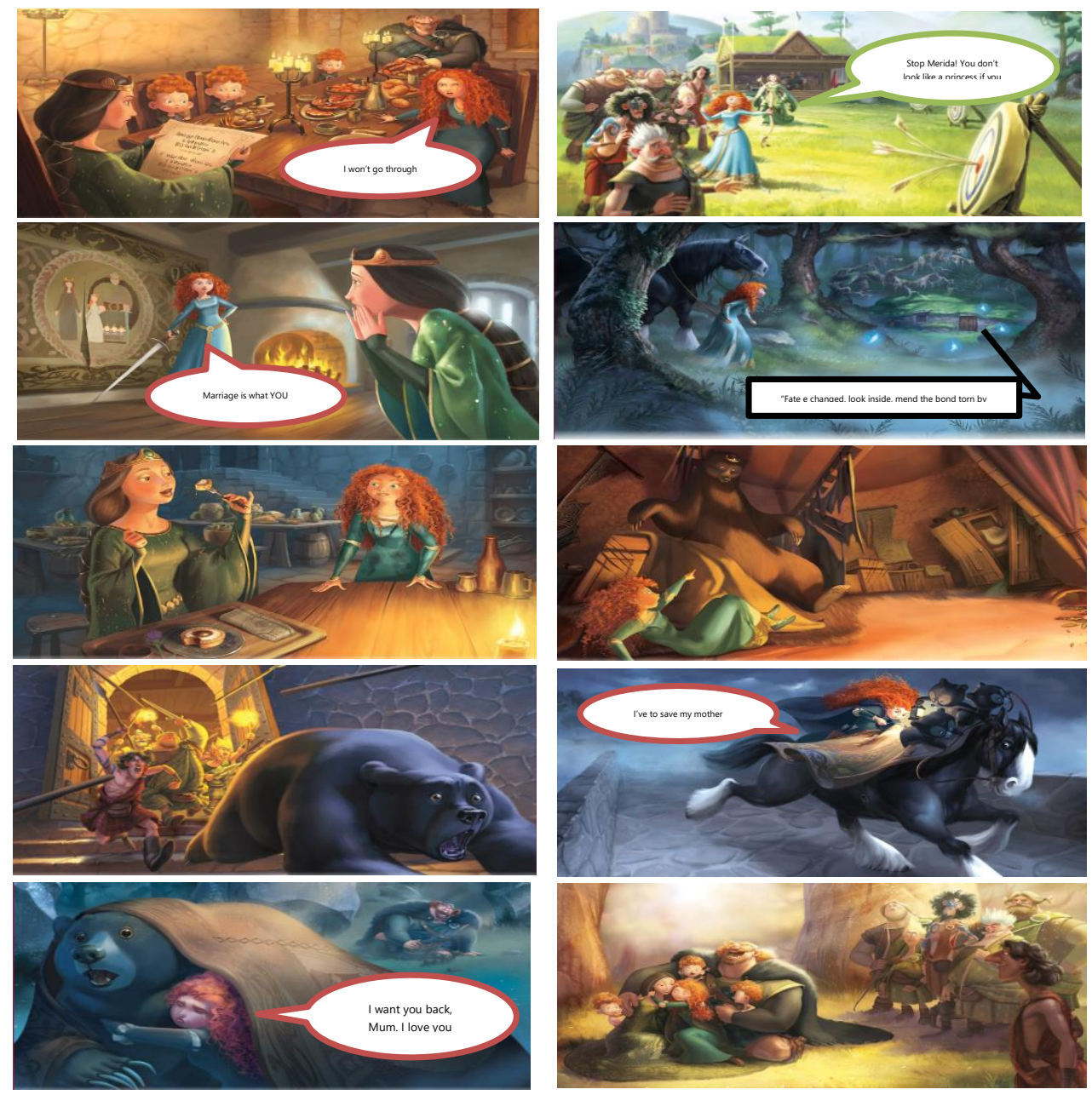


\section{METHOD}

The method that used in this research is quantitative research and pre-experimental research design conducted in one class. According to (Sugiyono, 2006:80) as cited in (Nuraeni \& Lube, 2020) the purpose of experimental research is to find the cause-effect relationship among the variables in controlled condition. And the objective of this research is to find out whether there is an influence of using comic strips as media in improving writing skills. The tenth grade students in one of SMKN in Cianjur were the population of this research and the sample was class X RPL that consist of 36 students in the academic year of 2019/2020. The data was collected with the pretest (gave before the teaching process) and posttest (gave after the teaching process was done) as the instrument.

\section{RESULTS AND DISCUSSION}

\section{Results}

In this part, the researcher used SPSS version 18 to answer whether the comic strips is effective to improve the tenth grade students' writing skill, with the title below:

Table 1. The result of Pre-test and Post-test

\begin{tabular}{|c|c|c|c|}
\hline No & Name & Pre-test & Post-test \\
\hline 1 & Student 1 & 35 & 70 \\
\hline 2 & Student 2 & 30 & 50 \\
\hline 3 & Student 3 & 66 & 70 \\
\hline 4 & Student 4 & 70 & 80 \\
\hline 5 & Student 5 & 66 & 75 \\
\hline 6 & Student 6 & 35 & 80 \\
\hline 7 & Student 7 & 30 & 60 \\
\hline 8 & Student 8 & 52 & 82 \\
\hline 9 & Student 9 & 35 & 75 \\
\hline 10 & Student 10 & 35 & 62 \\
\hline 11 & Student 11 & 75 & 77 \\
\hline 12 & Student 12 & 70 & 72 \\
\hline 13 & Student 13 & 55 & 62 \\
\hline 14 & Student 14 & 45 & 82 \\
\hline 15 & Student 15 & 52 & 62 \\
\hline 16 & Student 16 & 66 & 80 \\
\hline 17 & Student 17 & 30 & 62 \\
\hline 18 & Student 18 & 57 & 70 \\
\hline 19 & Student 19 & 57 & 75 \\
\hline
\end{tabular}




\begin{tabular}{|c|c|c|c|}
\hline 20 & Student 20 & 70 & 82 \\
\hline 21 & Student 21 & 82 & 90 \\
\hline 22 & Student 22 & 45 & 80 \\
\hline 23 & Student 23 & 57 & 80 \\
\hline 24 & Student 24 & 53 & 75 \\
\hline 25 & Student 25 & 32 & 70 \\
\hline 26 & Student 26 & 66 & 85 \\
\hline 27 & Student 27 & 58 & 90 \\
\hline 28 & Student 28 & 57 & 65 \\
\hline 29 & Student 29 & 62 & 70 \\
\hline 30 & Student 30 & 30 & 55 \\
\hline 31 & Student 31 & 50 & 75 \\
\hline 32 & Student 32 & 50 & 82 \\
\hline 33 & Student 33 & 66 & 75 \\
\hline 34 & Student 34 & 50 & 60 \\
\hline 35 & Student 35 & 40 & 55 \\
\hline 36 & Student 36 & 70 & 72 \\
\hline
\end{tabular}

Table 2. Normality test

\begin{tabular}{|l|r|r|r|r|r|r|}
\hline \multicolumn{1}{|c|}{} & \multicolumn{2}{|c|}{ Tests of Normality } \\
\cline { 2 - 7 } & \multicolumn{2}{|c|}{ Kolmogorov-Smirnov ${ }^{\mathrm{a}}$} & \multicolumn{3}{c|}{ Shapiro-Wilk } \\
\cline { 2 - 7 } & Statistic & df & Sig. & Statistic & df & \multicolumn{1}{c|}{ Sig. } \\
\hline Pretest & .135 & 36 & .097 & .941 & 36 & .057 \\
Posttest & .131 & 36 & .124 & .962 & 36 & .253 \\
\hline
\end{tabular}

a. Lilliefors Significance Correction

\section{Criteria:}

\section{If $\mathrm{Sig}>0.05$}

The sample was normal distribution.

The table shows that the Sig. of pre-test was 0.097 and the Sig. of post-test was 0.124 . Both of these data were higher than 0.05 , it can be conclude that the test has normal distribution. 
Table 3. Paired Samples Statistics

Paired Samples Statistics

\begin{tabular}{|rr|r|r|r|r|}
\hline & Mean & N & Std. Deviation & Std. Error Mean \\
\hline Pair 1 & Pretest & 52.75 & 36 & 14.810 & 2.468 \\
& Posttest & 72.42 & 36 & 9.898 & 1.650 \\
\hline
\end{tabular}

We can see that the mean of pre-test was 52.75 and the mean of post-test was 72.42 . The researcher continued to analyze paired samples test.

Table 4. Paired Samples Test

Paired Samples Test

\begin{tabular}{|c|c|c|c|c|c|c|c|c|c|}
\hline & & \multicolumn{5}{|c|}{ Paired Differences } & \multirow[b]{3}{*}{$\mathrm{t}$} & \multirow[b]{3}{*}{$\mathrm{df}$} & \multirow{3}{*}{$\begin{array}{l}\text { Sig. (2- } \\
\text { tailed) }\end{array}$} \\
\hline & & \multirow[b]{2}{*}{ Mean } & \multirow{2}{*}{$\begin{array}{c}\text { Std. } \\
\text { Deviation }\end{array}$} & \multirow{2}{*}{$\begin{array}{c}\text { Std. Error } \\
\text { Mean }\end{array}$} & \multicolumn{2}{|c|}{$\begin{array}{c}95 \% \text { Confidence } \\
\text { Interval of the } \\
\text { Difference }\end{array}$} & & & \\
\hline & & & & & Lower & Upper & & & \\
\hline Pair 1 & $\begin{array}{l}\text { Pretest - } \\
\text { Posttest }\end{array}$ & -19.667 & 12.396 & 2.066 & -23.861 & -15.473 & -9.519 & 35 & .000 \\
\hline
\end{tabular}

From the table shows that the significance value was $0.000(\mathrm{p}<0.05)$. So, the result of pre-test and post-test undergo significant changes. It means that comic strips media can improve students' writing skill.

\section{Discussion}

The researcher used pre-experimental design conducted in one class with implementation of pre-test in the first meeting, treatment was given twice using comic strips media (the second and the third day) and the in the last meeting, the post-test was given. After collecting the data, the researcher analyzed the data and it shows that there was a significant different of students achievement in pre-test and post-test. So, comic strips is an influence media to improve writing skill.

\section{CONCLUSION}

The use of comic strips in teaching learning activity have contributed to build skill in writing and of course the teacher must select the comic strips that are suitable with the material and teaching learning objectives. Based on the result, the researcher conclude that the comic strips has positive influence in improving students' writing skill. 


\section{ACKNOWLEDGMENTS}

Alhamdulillahirabbil'alamin. All praises be to Allah SWT who allowed the researcher to finish this article. It is completed on the result of hard work, support, and guidance of several people the researcher would like to express special thanks to Dra. Evie Kareviati, M.Pd. as my guide, my parents, my friends and all participants who have been willing to participate in the settlement of this article.

\section{REFERENCES}

Apsari, Y. (2018). Reflective Reading Journal in Teaching Writing. Indonesian EFL Journal, 4(2), 39. https://doi.org/10.25134/ieflj.v4i2.1374

Farizi, I., \& Fauzyah, F. (2019). the Use of Think Pair Share. 2(5), 752-756.

Herliana, W., \& Daniawati, E. D. (2018). Analysis Of Applying Song Media In English Learning Of Elementary School At Third Grade Students In Sdn Cibeber 1 Cimahi. 1(4), 383-390.

Hidayah, H., Mulyati, H. S., \& Suprijadi, D. (2019). Improving Students 'Ability to Write Narrative. 2(5), 634-639.

Lestari, W. I., Mawaddah, U., \& Kareviati, E. (2019). The Influence of Discovery Learning and Snowball Throwing Method in Improving. 2(3), 332-340.

Mahir, N. A., \& Ali, R. M. (2016). Using Newspaper Comics Strips To Improve Reading And Writing Among Muet Band 1 \& 2 Year 1 Students of Faculty of Quran And Sunnah Studies , Universiti Sains Islam Malaysia (Usim ). 2(3), 57-62.

Nuraeni, S., \& Lube, C. I. (2020). Improving English Vocabulary Mastery. 3(1), 109-113.

Yulianti, S., Nuraeni, S., \& Parmawati, A. (2019). Improving Students'writing Skill Using Brainswriting Strategy. Project (Professional Journal of English Education), 2(5), 714721. 